\title{
DEVELOPMENT OF GRAIN MARKET IN UKRAINE
}

\author{
Aleksandr MASLAK', Ihor KUTSCENKO², \\ Sumy National Agrarian University, Ukraine
}

\begin{abstract}
The subject of the research is a set of theoretical, methodological and practical fundamentals of organizational and economic functioning are integrated agricultural formations in the grain market of Ukraine. The methodological basis of research is the complex analysis of economic processes in the grain market in Ukraine and the world. During research we used such methods as method of systematization and comparison, statistic, economic, balance, constructive, target-oriented, and the methods of induction and deduction, analogy and comparison. Main aim of this article is the analysis of the situation on the grain market in Ukraine, defining the role of integrated agricultural formations in this market, improving the organizational-economic mechanism of its functioning, identifies ways of improving the competitiveness of Ukraine among world exporters of grain. Using results of the studies we examined trends grain market in Ukraine; influence of businesses in grain production; analysis of constraints to improve production efficiency of grain; defined domestic (internal) needs of grain in Ukraine; assessed the status and expediency transformation infrastructure of the grain market of Ukraine; defined priority directions of development of the grain market in Ukraine. As a result of the preparation of articles, it is obtained the following conclusions: Ukraine is the world's largest producers and exporters of grain, the production of integrated agricultural units to a third of the total grain; technical condition of farm does not meet the needs of production; the domestic market is unable to provide the existing demand for grain production, contributing to export growth; Ukraine has a number of problems due to increased grain production, namely the shortage of storage capacity for the storage of grain, limited performance transshipment of grain in port elevators and imperfection and depreciation of transport systems; solving the existing problems is possible through the implementation of state and regional programs, implementation of joint projects with partner companies and the purchase of equipment and facilities through leasing programs. As a result of the development of logistics infrastructure of grain market provides employment generation, value-added products that will increase revenues to the state and local budgets. Besides Ukraine reach the strategic goal of producing $80 \mathrm{mln}$. tons of grain and strengthen positions in the global agricultural market.
\end{abstract}

Key words: grain market, integrated agricultural farm, grain production, the world grain market.

JEL Classification: Q13, Q12, Q17

\section{Introduction}

Topicality. Grain production among the leading sectors of agriculture in Ukraine. Over the last decade Ukraine significantly increased the production and export of grain. The country ranks ninth among world producers of wheat, fifth - for the production of corn and barley. In general, Ukraine is in third place in the world in terms of grain exports.

Growing crops involved in various forms of management, production scale, technical and staffing. However, the top spot on the production and export of grain owned integrated agrarian formation. The level of organization and resources affects the efficiency of management. The profitability of grain production in 2014 slightly above inflation. This situation hinders innovation in farm activities and further development of the industry.
The purpose and objectives. The article aims to analyze the situation on the grain market in Ukraine, defining the role of integrated agricultural formations in this market, improving the organizational and economic mechanism of its functioning, identify ways of improving the competitiveness of Ukraine among world exporters of grain. To achieve this goal it is necessary to solve specific scientific problems, namely to consider the trends of grain market in Ukraine; determine the impact of businesses on grain production; to analyze constraints to improve production efficiency of grain; define domestic needs of grain in Ukraine; assess the state and prove the expediency of transforming the infrastructure of the grain market of Ukraine; outline priority directions of the grain market in Ukraine.

Methodology. The methodological basis of research defines complex analysis of economic processes in the

Corresponding author:

${ }^{1}$ Department of Logistics and Production Management, Sumy National Agrarian University.

E-mail: almaslak@ukr.net

${ }^{2}$ Department of Logistics and Production Management, Sumy National Agrarian University .

E-mail: snaulogistika@mail.ru 
grain market in Ukraine and the world. Systematization and comparison methods studied world trends and domestic grain market. Assessment of the market of grain held statistical and economic, balance, constructive methods. In studying the infrastructure of the grain market in Ukraine and to prepare proposals for its optimization techniques used - induction and deduction, analogy and comparison. Definition of priority directions of the grain market in Ukraine was conducted using program budgeting.

Information base of research is scientific papers, theoretical and practical research set out in international and domestic literature, laws and regulations on the formation and functioning of the grain market. Empirical research base materials constituted State Statistics Service of Ukraine, the results of analytical studies of news agencies and NGOs.

\section{Analysis of recent research and publications}

Research on the development of the world economy and the domestic grain and grain market dedicated work of economists: V.G. Andriychuk, P.I. Haidutsky, V.M. Heyts, O.V. Zakharchuk, S.M. Kvasha, M.G. Lobas, B.Y. Paskhaver, V.Yu. Protasov, P.T. Sabluk, V.F. Saiko, V.P. Sytnyk, O.M. Shpychak and others. Most studies concerning the beginning of market relations and do not cover the current organizational and economic mechanism of grain market in Ukraine. At the same time the current level of domestic grain production capacity and necessitate scientific support continuous improvement strategies for the development of the grain market and in particular the integration processes.

In turn, theoretical and methodological aspects of integration processes covered in papers of I. Ansoff, M. Benoit, M. Bradley, P. Coulomby, Karl Marx and other scientists. Significant contribution to the study of this issue did V.G. Andriychuk, V.I. Boyko, P.I. Haidutsky, S.M. Kvasha, P.K. Kaninsky, M.Yu. Kodenska, I.H. Kyrylenko, M.F. Kropyvko, I.I. Lukinov, Yu.O. Lupenko, M.Y. Malik, P.M. Makarenko, V.Y. Mesel-Veselyak, Yu.O. Nesterchuk, P.T. Sabluk, O.H. Shpykulyak, M.M. Fedorov and others. A significant contribution to the development of economic relations at the farm level, such Ukrainian scientists as M.V. Hladiy, O.V. Krysalny, M.I. Pugachov, H.M. Pidlisetsky, V.P. Sytnyk A.M. Stelmashchuk, S.O. Yushin and others. Theoretical and practical fundamentals of production management are reflected in the works of foreign scholars and practitioners of management such as D. MacGregor, F. Taylor, A. Fayolle and others.

Accumulated theoretical and methodological material in the field of integration processes may serve as a basis for research in this area. However, the lack of stability of the agricultural sector, the need to introduce effective forms of production require in-depth study of specific units and integrated agricultural development of effective mechanisms to improve their activities.

\section{Production}

By results of 2014 the volume of gross output of agricultural sector amounted to 251.4 billion UAH. (in comparable prices of 2010), which is less than the previous year at 1.4 billion UAH. The structure of the industry is dominated by crop production. Moreover, in recent years the tendency to increase the share of crop production in gross production. If in 2010 it was $63.9 \%$ in 2014 it rose to 70.7 percent (Table. 1) [Agriculture in Ukraine, 2015; Adoption of Social Facilities and Production Capacities in Ukraine 2014 (2015)].

The share of gross output of grain and leguminous crops in total gross plant production during the years 2010-2014 was located within $33-38 \%$ and in 2014 reached almost $27 \%$ of total gross agricultural production. These data confirm the importance of grain production in agricultural development.

In 2014, agriculture in Ukraine engaged nearly 53 thousand enterprises. 45,000 of these used agricultural land. The total area of land use in these companies was 22 million hectares. In addition, at the beginning of 2014 in Ukraine operated 78 integrated formation with total agricultural land area of over 10 thousand hectares. In general, in their land-use were 5.85 million hectares, or nearly $28 \%$ of agricultural land in Ukraine [The Largest Agricultural Holdings in Ukraine, 2014].

In 2014 Ukraine produced 63.9 million tons of grain. Output of food grain was 25.1 million tons $(39 \%$ of the total), fodder - 38.8 million tons (61\%). Compared to the year 2013, grain production increased by $2.5 \%$. This figure was determined by excluding the temporarily occupied territory of the Autonomous Republic of Crimea and the zone of the antiterrorist operation. This is a record for Ukraine. Per capita Ukraine produced $1,485 \mathrm{~kg}$ of grain.

Table 1

Gross agricultural production, bln. UAH

\begin{tabular}{|l|c|c|c|c|c|c|}
\hline \multirow{2}{*}{\multicolumn{1}{|c|}{ Indicators }} & \multicolumn{5}{c|}{ Years } \\
\cline { 2 - 7 } & 2005 & 2010 & 2011 & 2012 & 2013 & 2014 \\
\hline Gross production - total & 179,6 & 194,9 & 233,7 & 223,3 & 252,9 & 251,4 \\
\hline crop production & 114,5 & 124,6 & 162,4 & 149,2 & 175,9 & 177,7 \\
\hline demsity of crop production, \% & 63,7 & 63,9 & 69,5 & 66,8 & 69,6 & 70,7 \\
\hline grain and leguminous crops & 41,7 & 41,6 & 60,5 & 49,4 & 67,0 & 67,6 \\
\hline density of grain and leguminous crops , \% & 23,2 & 21,4 & 25,9 & 22,1 & 26,5 & 26,9 \\
\hline livestock production & 65,1 & 70,3 & 71,3 & 74,0 & 77,0 & 73,7 \\
\hline density of livestock production, \% & 36,3 & 36,1 & 30,5 & 33,2 & 30,4 & 29,3 \\
\hline
\end{tabular}


The increased production achieved mainly by improving productivity. Total yield of grain in 2014 totaled $43.7 \mathrm{c} / \mathrm{ha}$, up 3.1 centers from 1 hectare (or 7.6\%) more than in 2013 year. Sown area under grain crops was 14.8 million hectares, less than in the year 2013 by $5.6 \%$ (Fig. 1) [Harvesting of Crops, Fruits, Berries and Grapes in the Regions of Ukraine 2014 (2015)].

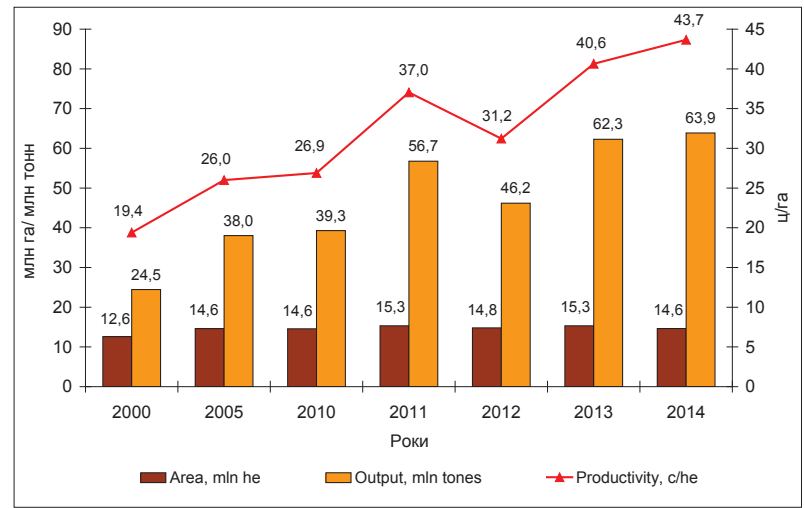

Fig. 1. Dynamics of grain production in Ukraine

In 2014 grains produced 34.4 thousand agricultural enterprises. Their total production was up to 49.9 million tons. Average grain production from 1 ha was 47.5 metric centers. Thus, the productivity of large grain trade enterprises was higher than small businesses. Enterprises of grain production over 5 thousand tones received 58.1 metric centers of grain per hectare. Companies with grain production to 5 thousand tons 34.5 metric centers.

In addition to agricultural enterprises, grain also producing by households. In 2014, they produced nearly $14 \mathrm{mln}$. tons of grain, which is $28 \%$ of total production.

Significant contributions to the development of grain farming in Ukraine carry out integrated agricultural farm. In 2013, the area of cultivation of cereal crops in integrated agricultural formations totaled 3.27 million hectares, which is $3 \%$ more than the previous year. Total grain production was 19 million tones, a third more than the previous year. The share of grain produced integrated agricultural units was $30 \%$ of total production in Ukraine. The average yield of grain crops in integrated agricultural formations totaled $59.1 \mathrm{c} / \mathrm{ha}$, which is $29 \%$ more than the previous year [The Largest Agricultural Holdings in Ukraine, 2014].

Following the economic activity of agricultural enterprises in 2014 the profitability of crop production was up to $29.2 \%$. This is more than in 2013 by $18.1 \%$. The yield of grain increased from $1.5 \%$ in 2013 to $25.8 \%$ in 2014 . One of the factors influencing the profitability of grain production increase was higher prices of products. Average selling price for crop production increased compared 2013 to $29.2 \%$, including grain went up by $38.9 \%$ [Main Economic Indicators of Agricultural Production in the Agricultural Enterprises for 2014].

\section{Investment Need}

Technical condition of farm does not meet the needs of production. Machine and tractor fleet morally and technically worn out and provided only by $60-65 \%$ and technological needs. Operation of outdated technology leads to frequent downtime because of maintenance and adjustment. Consequently, the delay time seasonal field work, violated technological requirements of growing crops, which negatively affects the quality of the crop and increase its losses.

According to the Department of Engineering Support and Agricultural Machinery Ministry of Agrarian Policy and Food of Ukraine minimal scientifically accurate annual update of tractor fleet to the technological needs estimated at 35 billion, including about 40 thousand units of tractors (15 billion UAH) and nearly 7 thousand grain combines (10.5 bln. UAH) (Tab. 2).

Table 2

Technological needs of agricultural enterprises in machinery to produce projections grain output

\begin{tabular}{|l|c|c|}
\hline \multicolumn{1}{|c|}{ Name and type } & $\begin{array}{c}\text { Total quantity, } \\
\text { un }\end{array}$ & $\begin{array}{c}\text { Annual need, } \\
\text { un }\end{array}$ \\
\hline Grain Harvesters & 75000 & 7500 \\
\hline Corn Harvesters & 9500 & 950 \\
\hline $\begin{array}{l}\text { Prefixes to grain harvester for } \\
\text { corn harvesting }\end{array}$ & 14600 & 1400 \\
\hline Rolling harvester & 36200 & 3600 \\
\hline $\begin{array}{l}\text { Sewing machine grain crops } \\
\text { combined }\end{array}$ & 102500 & 10000 \\
\hline $\begin{array}{l}\text { Sewing machine for corn } \\
\text { Machines and devices for } \\
\text { clearing }\end{array}$ & 12000 & 4900 \\
\hline Mechanical grain loaders & 38400 & 3800 \\
\hline
\end{tabular}

Result of author' research on the basis of NSC "Institute of Mechanization and Electrification of agriculture" NAAS of Ukraine

Grain production is one of the more attractive investment activities. As a result of questioning farm managers - its enough to invest in the beginning of activity in average of 1 to 2 thousand USD per 1 hectare with an average payback period of investment is 4-5 years. However, farmers produce some risks that hinder investment in growing crops. Mostly it concerns possible government intervention in export control. Doing so may lead to lower prices on the domestic market and hinder the realization of agricultural products.

In addition, there are risks that depend on state regulation of land market in Ukraine. Although the moratorium on sale of agricultural land was extended to 2016, the lack of an effective legislative framework and coordinated actions sectoral institutions are perceived by investors as additional risks.

When considering investment options more attractive are large companies, including integrated agricultural enterprises that will be able to further increase the capacity of businesses. In addition, an important factor 
is the availability of facilities for storage and processing. This greatly reduces the risks that can arise from price fluctuations and increases the profitability of such activities.

\section{Impact of the global market}

In the 2015/16 marketing year (MY) Ukraine reduced production and domestic needs of grain. According to analysts, grain production will exceed 60 million tons, and consumption within the country will reach 26.9 million tones, $6.5 \%$ less than the previous season (27.3 million tons). This trend is observed due to a decrease of $10 \%$ compared to last season volumes of feed grains. At the same time, consumption of food grain will increase. If last year processed food targets 4.7 million tons in the current expected corresponding increase to 4.9 million tons. Such expectations caused by the retention in the current season on a high level of sales of flour to foreign markets. Accordingly, production and consumption of these products increase. However, grain exports will be top priority.

According to the August report of the Food and Agriculture Organization (FAO), world production of grain in 2015 will amount to 2.5 billion tones, 13.8 million tones more than the previous month's estimates. Increased production is expected to increase yields by forage crops, wheat and rice. This contributed to the improvement of weather conditions, growing corn in Argentina, Brazil and the USA. In turn, the information on the reduction of maize production in the EU due to hot weather conditions less influence on the world balance of this type of grain.

Forecast world wheat production in 2015 is more optimistic. Its harvest will be 728 million tones, 5 million tones forecast to exceed previous periods. In Australia, the EU, the Russian Federation and Ukraine are expected to grow wheat. This effect expanding acreage and favorable weather conditions. So increase wheat yields of these countries with surplus compensates its decrease in Canada, where the main production regions of the grain affected by drought.

FAO forecast of world stocks of grain on the end of season in 2016 increased to 643 million tones, almost 12 million tones more than in the previous forecast periods. Ensuring global demand, growth stocks of grain affects the price situation.

During August on the world grain market there was a decline in prices for basic grains. In addition to the growth of grain production in the countries of its main producers, the price reduction was also affected by the financial and economic crisis unfolding in China. Therefore, the market experts have warned of a possible decline in the pace of global economic growth and reduce global demand for grain. Following the August index of world prices for grains and oilseeds (GOI) of the International Council of grain (IGC) dropped by $4.8 \%$, while wheat price index fell by $4.3 \%$, maize - $1 \%$, barley - 42 per cent. However, due to the devaluation of the hryvna, lower world grain market prices are less noticeable in the domestic market of Ukraine.

Despite the unfavorable economic and political conditions in the country and low prices on world markets, Ukraine's agricultural sector continues to develop. Its share in the gross domestic product of Ukraine reaches 14 percent. Agricultural production is the main source of foreign currency in Ukraine.

According to analysts of the domestic market this year with the possibility of Ukraine grain exports stay within 33 million tons. This is lower than previous estimates due to lower production forecasts and external sales of corn. It is expected that the volume of new crop corn exports will be up 13 million tons. Following the August-September this year, the rate of export of grain from Ukraine is $24 \%$ higher than last year. As of September 10, exported nearly 7 million tones of grain, of which: wheat - 3.4 million tons, corn - 1.3 million tons, barley - 2.2 million tons.

The devaluation of the national currency has become a stimulus for the intensification of export trade of agricultural products. In Ukraine actively conducting a search for new markets for grain and its products on all continents. The government hopes the end of 2015 every third dollar export will arrive in Ukraine's economy from the agricultural sector. According to estimates of farmers in this period will provide income $\$ 4$ billion foreign exchange earnings. That September-December is supposed to sell for export 20 million tons of grain throughputs at the logistics infrastructure of the internal market. Thus the majority of the grains account for wheat and barley. Consequently, in the 2015/16 marketing year despite the decline in grain production, Ukraine will keep busy in previous years the position of leader of world grain exports.

\section{Problems}

The domestic market is unable to provide the existing demand for grain production, contributing to export growth. Ukraine has officially defined strategic goal to bring grain production to $80 \mathrm{mln}$. tons. However, according to experts, the increase in grain production could lead to problems for market participants.

Firstly, Ukraine does not have enough capacity to store grain. To cancel mandatory certification in Ukraine

Table 3

Power of commissioned facilities for storing grain, thousand tons of simultaneous storage

\begin{tabular}{|l|c|c|c|c|}
\hline \multicolumn{1}{|c|}{ Object name } & 2013 & 2014 & First half of 2015 & 2014 to $2013, \%$ \\
\hline Forage storage & 76,2 & 141,2 & 9,0 & in 1,9 times \\
\hline Elevators & 2001,6 & 833,1 & 298,2 & 41,6 \\
\hline Granaries mechanized & 217,2 & 709,7 & 45,2 & in 3,3 times \\
\hline Cleaning and grain cleaning and drying objects & 3514,7 & 3868,3 & 642,5 & 110,1 \\
\hline
\end{tabular}


operated about 790 "certified" grain storage capacity of about 33.5 million tons. Other warehouses and grain elevators or provide quality services or do not have adequate technical equipment. That is, even when the grain harvests $60 \mathrm{mln}$. tones and oilseeds at $15 \mathrm{mln}$. tons shortage of quality warehousing capacities. Following the 2014 totally was commissioned 92 grain storage facilities with total capacity of $5.6 \mathrm{mln}$. tons (Tab. 3) [Adoption of Social Facilities and Production Capacities in Ukraine 2014 (2015)].

Secondly, the Ukrainian ports can restart within one month export 2,8-3,0 mln. tons of grain. Therefore, with the increase in production should increase capacity of port elevators.

However, most of the grain in Ukraine transported by rail. Over the past five years, the share of transport in total traffic is about 65 percent. In Ukraine there are about 13.6 thousand of grain trucks, with an average age of 26 years. This normative service life is 30 years. Therefore, the third problematic issue is the inadequacy and obsolescence first rail transport system.

One of the main problems in the development of the logistics infrastructure of the agricultural sector is their limited financial resources activities. For most farmers the sources of the funds are proceeds from the sale of products and services, borrowing from banks, state support.

During 2014-2015 years, farmers have increased their incomes, but also increased costs. During the same period inputs used in agriculture increased by 2 and sometimes 3 times. The prices sales increased on average by 1.5-2 times. It certainly marked on the availability of funds that can be spent on projects of infrastructure development companies.

The possibility of raising funds is bank lending. However, credit conditions in the current period of economic and political instability in the country have few appealing. Lending rates of banks related services in excess of $30 \%$ per annum. For comparison, the results in 2014 the profitability of farming farmers amounted to 26.4 percent. That is the involvement of bank loans will be an additional financial burden on farmers.

More farmers have adopted for government programs targeted allocation of funds for the construction of logistics infrastructure and provide appropriate equipment. However, such programs in recent years or are not funded from the budget allocated funds are sufficient to meet the needs of businesses.

\section{Solutions}

The development of logistics infrastructure of grain market provides employment generation, value-added products, leading to increased revenues to the state and local budgets. Therefore, the state should be interested in restoring funding programs of industrial and logistics infrastructure of agricultural enterprises. This state and regional funding program farmers can provide funding to the return or without their return, compensation for the use of bank long-term loans and so on.

One of the sources of funds for the development of logistics infrastructure investment can be partner companies. Thus the funds allocated to the development of agricultural enterprises on the Rights of the equity release companies partners share in the ownership of such companies.

Renewal of warehousing equipment, purchase of vehicles can be carried out on lease through banking institutions collaborating with supplying machinery or equipment. The feature of such contracts is to use the necessary means of production to the date on which the final payment.

\section{Conclusions}

1. Ukraine is the world's largest producers and exporters of grain. The gross grain production in the country is growing. Following the results of 2014 produced nearly 64 million tons of grain. This integrated agricultural produce to the formation thirds of total grain.

2. Technical condition of farm does not meet the needs of production. However, when considering investment options more attractive large companies, including integrated agricultural farm.

3. The domestic market is unable to provide the existing demand for grain production, contributing to export growth. In the 2015/16 marketing year despite the decline in grain production, Ukraine will keep busy in previous years the position of leader of world grain exports.

4. Ukraine has a number of problems due to increased grain production, namely the shortage of storage capacity for the storage of grain, limited performance transshipment of port grain in elevators, as well as depreciation and imperfection of transport system.

5. Solution of problems is possible through the implementation of state and regional programs, implementation of joint projects with partner companies and the purchase of equipment and facilities through leasing programs.

As a result of the development of logistics infrastructure of grain market provides employment generation, valueadded products that will increase revenues to the state and local budgets. Besides Ukraine reach the strategic goal of producing $80 \mathrm{mln}$. tons of grain and strengthen positions in the global agricultural market.

\section{References}

Agriculture in Ukraine (2015). Report. State Statistics Service of Ukraine, 12 p.

Adoption of Social Facilities and Production Capacities in Ukraine 2014 (2015). Statistical Bulletin. State Statistics Service of Ukraine, $115 \mathrm{p}$.

Harvesting of Crops, Fruits, Berries and Grapes in the Regions of Ukraine 2014 (2015). Statistical Bulletin. State Statistics Service of Ukraine, $52 \mathrm{p}$. 
Main Economic Indicators of Agricultural Production in the Agricultural Enterprises for 2014 (2014). Statistical Bulletin. State Statistics Service of Ukraine, 84 p.

Plant Production in Ukraine 2014 (2015). Statistical Yearbook. State Statistics Service of Ukraine, 180 p.

The Largest Agricultural Holdings in Ukraine (2014). Research agency AgriSurvey Ukrainian Club of Agrarian Business, $64 \mathrm{p}$.

\section{Александр МАСЛАК, Игорь КУЦЕНКО}

РАЗВИТИЕ РЫНКА ЗЕРНА В УКРАИНЕ

Аннотация. Предметом исследования является совокупность теоретических, методологических и практических основ организационно-экономического функционирования интегрированных аграрных формирований на рынке зерна Украины. Методологической основой исследований определено комплексный анализ хозяйственных процессов на рынке зерна в Украине и мире. При проведении исследований использовались методы систематизации и сравнения, статистико-экономический, балансовый, расчетно-конструктивный, программно-целевой, а также методы индукции и дедукции, аналогии и сравнения. Целью статьи было проведение анализа ситуации на рынке зерна в Украине, определение роли интегрированных аграрных формирований на этом рынке, совершенствования организационно-экономического механизма его функционирования, определение путей повышения конкурентоспособности Украины среди мировых экспортеров зерна. По результатам проведенных исследований рассмотрены тенденции развития рынка зерна в Украине; определенное влияние субъектов хозяйствования на объемы производства зерна; проведен анализ сдерживающих факторов повышения эффективности производства зерна; определены внутренние потребности зерна в Украине; оценены состояние и обоснована целесообразность трансформации инфраструктуры рынка зерна Украины; очерченные приоритетные направления развития рынка зерна в Украине. По результатам подготовки статьи были получены следующие выводы: Украина входит в число крупнейших мировых производителей и экспортеров зерна, при производстве интегрированными аграрными формированиями до трети общего объема зерна; техническое состояние сельскохозяйственных предприятий не соответствует потребностям производства; внутренний рынок не в состоянии обеспечить спрос на существующие объемы производства зерна, что способствует росту экспорта; в Украине существует ряд проблем из-за увеличения производства зерна, а именно дефицит складских мощностей по хранению зерна, ограниченность производительности по перегрузке зерна в припортовых элеваторах, а также изношенность и несовершенство железнодорожной системы; решения существующих проблем возможно через государственных и региональных программ, реализацию совместных проектов с компаниями партнерами а также приобретение оборудования и технических средств через программы лизинга. Как результат развитие логистической инфраструктуры рынка зерна обеспечивает создание рабочих мест, добавленной стоимости продукции, что повлияет на увеличение поступлений в государственный и местные бюджеты. Кроме этого Украина достигнет стратегической цели по производству 80 млн. тонн зерна и укрепит позиции на мировом аграрном рынке. 